\title{
LADINA TERMINID TSIVILÕIGUSES: EESTIKEELSED ORIGINAALÕPIKUD VERSUS TÕLKEÕPIKUD
}

\section{Merike Ristikivi}

\begin{abstract}
Ülevaade. Artikkel käsitleb ladina terminite esinemist eestikeelses tsiviilõiguse õppekirjanduses. Uurimismaterjaliks on kaheksa õpikut tsiviilōiguse eri valdkondadest (asjaõigus, võlaõigus, pärimisõigus, perekonnaõigus ja tööõigus). Kontinentaalne õigus lähtub Rooma tsiviilõigusel põhinevast mõistete süsteemist ning ladina terminite osa on tsiviilõiguses suurem kui teistel õigusaladel. Kuna Eesti praeguse õiguse aluseks on võetud Saksa õigus, siis on uuritavate õpikute hulgas lisaks eestikeelsetele originaalidele ka saksa keelest eesti keelde tõlgitud õppematerjal, eesmärgiga võrrelda ladina terminite kasutamist eesti ja tõlkeõpikutes ning Saksa õiguse võimalikku mõju terminoloogilisel tasandil. Artikkel uurib ka erinevusi ladina terminite kasutamisel tsiviilõiguse eri valdkondades, arvestades seoseid tsiviilõiguse harude ajaloolise arenguga.
\end{abstract}

Võtmesõnad: õiguskeel, terminoloogia, keeleala uurimine, keelekontaktid, ladina keel, eesti keel

\section{Sissejuhatus}

Ladina õigusterminite esinemise uurimine õpikutes on jätk varasematele töödele, milles olen käsitlenud ladina termineid õigusajakirjade artiklites ja võõrterminite kasutamisega kaasnevaid praktilisi probleeme (Ristikivi 2007, 2008). Need uurimused näitasid, et taasiseseisvusaja juriidilistes ajakirjades on ladina terminite kasutus aastate jooksul märgatavalt suurenenud. Terminikasutust on eriti muutnud Euroopa Liiduga liitumine, mis on sidunud Eesti jälle euroopaliku ja ladina keele alusel kujunenud õigusruumiga.

Mis on aga alus, mille baasilt juuratudengid artiklites leiduvaid termineid peaksid tundma ja mõistma? Kuidas omandatakse sõnavara ja milline see on? Ladina 
keele ja õigusterminoloogia õppimine on tänastele juuratudengitele kohustuslik. ${ }^{1}$ Kuna ladina keelt õpetatakse praegu vaid üksikutes Eesti gümnaasiumides, puutub enamik üliõpilastest esmakordselt ladina keelega kokku alles ülikoolis. 30 auditoorse õppetunni (loengud ja seminarid) käigus omandatakse häl̈ldusreeglid, grammatika põhitõed ja sõnavara, mis hõlmab küll ka karistusõiguse, rahvusvahelise õiguse jt termineid, kuid keskendub samuti esimesel õppeaastal toimuvat kohustuslikku Rooma eraõiguse kursust silmas pidades eelkõige vastavale leksikale ja allikmaterjalile. Enamik tänapäevases tsiviilõiguses (kus ladina keele mõju terminoloogiale on olnud kõige suurem) käibivatest ladina terminitest pärineb Antiik-Roomast ja nende vormiline külg õpitakse ära ka ladina keele kursusel. Seega näiks ju kõik korras olevat. Ent uurimistulemused näitavad, et ladina terminite kasutamisel esineb eksimusi ka semantilisel tasandil.

Michael Halliday ütleb, et probleemid erialases terminoloogias ei tulene tavaliselt mitte termineist endist, vaid terminite vahelistest komplekssetest seostest. Ta märgib, et oskussõnu ei saa defineerida isoleerituna, neid tuleb käsitleda kui osa suuremast raamistikust ning igaüht tuleb määratleda seoses kõigi teistega (Halliday 2004: 162). Seetõttu, kuigi ladina keele tunnis käsitletakse põhjalikult terminite ortograafia ja morfoloogia küsimusi, ei ole samal ajal siiski võimalik edasi anda kõiki sisulisi aspekte. Täpsem teadmine termini toimimisest reaalses õigussituatsioonis omandatakse vastava valdkonna loengukursustel ja õppematerjali abil.

Käesolevas artiklis uurin, millised ladina terminid esinevad eestikeelses tsiviilõiguse õppekirjanduses ja kui palju neid on. Tsiviilõigus on valitud põhjusel, et selle valdkonna ajaloolise arengu tõttu on ladina keele osa selles suurem kui teistel õigusaladel. Varasematest uurimustest selles vallas saab nimetada Heikki E. S. Mattila artiklit, milles on võrreldud pärimisõiguses esinevaid ladina termineid Soome, Saksa, Inglise ja Prantsuse pärimisõiguse õpikutes (Mattila 2006b) ning käesoleva kirjatöö koostaja eelnimetatud artikleid.

Uuritava kaheksa õpiku hulgas, mis puudutavad tsiviilõiguse eri valdkondi, on lisaks eestikeelsetele originaalidele ka saksa keelest tõlgitud õppematerjal. Ühelt poolt on Saksa õiguse mõju Eesti õiguskultuurile olnud märkimisväärselt suur ning Saksa õigus on võetud ka Eesti praeguse õigusloome aluseks. Teiselt poolt ei ole taasiseseisvumisaja jooksul kõigis tsiviilõiguse harudes eestikeelseid originaalôpikuid kirjutatud ning õppetöös kasutatakse eesti keelde tõlgitud õppevahendeid. Uurimisküsimusena vaatlen sellelt taustalt, kas Saksa õiguse mõju kajastub ka terminoloogilisel tasandil ehk milline on ladina terminite kasutamise suhe eesti ja tõlkeõpikutes? Ühtlasi vaatlen, millised erinevused esinevad ladina terminite kasutamisel tsiviilõiguse eri valdkondades. Oletan, et ladina terminite kasutamine on seotud tsiviilõiguse harude ajaloolise arenguga. Alamhüpoteese on kaks: 1) ladina keel esineb sagedamini asjaõiguses, võlaõiguses ja pärimisõiguses, kus terminoloogia on suuremas osas kujunenud antiik- või keskajal); 2) vähem võib leida ladina termineid töö- ja sotsiaalhooldusõiguses ning perekonnaõiguses, mille kujunemine ja uurimine on toimunud peamiselt 20. sajandil. Side Rooma õigusega, millest on käibesse läinud enamik ladina tsiviilõiguse termineid, neil puudub või on kaudne. 


\section{Ainestik}

Mandri-Euroopa tsiviilõigus kuulub nende õigusharude hulka, mille terminoloogia ja alusmõisted on saanud alguse antiikajal ladina keele baasil. Aastatel $451-450 \mathrm{eKr}$ pandi kirja "Kaheteistkümne tahvli seadused" (Leges duodecim tabularum), mis panid aluse Rooma õiguse edasisele arengule (Tamm 1997: 191). ${ }^{2}$ Ladinakeelsena koostati 6. sajandil keiser Justinianuse korraldusel ka Rooma õiguse tähtsaim koodeks Corpus Iuris Civilis ('Tsiviilõiguse kogumik'), mis on otseselt mõjutanud Euroopa tsiviilõiguse kujunemist (Birks, McLeod 1987: 18). Corpus Iuris Civilis'e uurimisel põhines ka Rooma õiguse retseptsioon. Rooma õiguse taassündi seostatakse Lääne-Euroopa aladel eelkõige ülikoolide rajamisega 11.-12. sajandil. Rooma öiguse taasavastamine Itaalias (eriti Bologna ülikoolis), Hispaanias ja Prantsusmaal, aga ka Inglismaal, viis Rooma õiguse uuesti õitsele. Peamiselt haaras retseptsioon tsiviilōigust, karistus- ja protsessiõiguse alal olid keskajal välja kujunenud juba uued normid või tavad (Hattenhauer 2007: 271-283, Wieacker 1967: 97-103, 124-152, 243-248, Koschaker 1966: 124-163). Kõige viimasena, 16. sajandil, tungis Rooma õigus Saksamaale, kus ta samas saavutas kõige ulatuslikuma rakenduse (Mattila 2006b: 132). Kuivõrd keskaegsed hariduskaanonid baseerusid nn seitsmel vabal kunstil (septem artes liberales), kandus õigusteaduslik traditsioon edasi eeskätt retoorika, grammatika, loogika/dialektika kaudu, mis moodustasid põhihariduse ehk kolmiktee (trivium) ja mille käigus loeti ja kirjutati ümber ka antiikõiguse säilinud tekste. Rooma õiguse retseptsioon tegi Corpus iuris civilis'est peamise õpetamis-ja uurimisobjekti, sellesse koondatud tekstid olid õigusteadlastele kirjaliku kuju omandanud mõistus ja tarkus (ratio scripta). (Senn 2007: 166-167, Hattenhauer 2007: 271-277) Eriti põhjalikult uuriti võla- ja asjaõigusega seotud tekste, neid sätteid kommenteeriti ning püüti tõlgendada ja kohandada vastavalt kaasajale ja eluvajadustele ning praktiliste küsimuste lahendamiseks. Sajandite jooksul ei pälvinud uurijate tähelepanu sellise põhjaliku töö juures mitte ainult õigusteoreetiline ja -ajalooline aspekt, vaid püüti kindlaks määrata ka kodifikatsiooni algteksti ning seetõttu oli vaja ka tekste kriitiliselt ja filoloogiliselt analüüsida (Görgen 2002: 39-46).

19. sajandil süstematiseeriti selline kirjalikult fikseeritud ja dogmaatiliselt kommenteeritud õigus põhjalikult ja nii kujunes Rooma õigusest üks tänapäevase Mandri-Euroopa tsiviilõiguse põhialus (Narits 1997: 5).

Eesti praeguses õiguses on terminid tsiviilõigus ja eraõigus sisuliselt sünonüümid. ${ }^{3}$ Eesti tsiviilõiguse süsteem on üles ehitatud Pandektide ${ }^{4}$ põhimõttele, mille järgi kõik tsiviilõiguse normid jaotatakse kahte rühma, millest üldosa reguleerib tsiviilõiguse üldpõhimõtteid ning eriosa puudutab asjaõigust, perekonnaõigust, pärimisõigust ja obligatsiooni- ehk võlaõigust ning viimase osana ka tööõigust. Rooma klassikalises õigusteaduses oli tsiviilõigus (ius civile) eraõiguse (ius privatum) üks allikas ning tähistas eelkõige riigi kodanikesse (cives) puutuvat ja nende õigussuhteid reguleerivat õigust. ${ }^{5}$ Tsiviilõiguse kasutamine praeguses tähenduses

2 Kaheteistkümne tahvli seaduste eestikeelset tõlget vt Annus jt 2001: 257-288.

3 Sama sisuline sünonüümia ka Saksamaal. Soomes on tsiviilõigus eraõiguse osa, mille juurde ei loeta töö- ja sotsiaalhooldusõigust ega keskkonnaõigust. Prantsusmaal aga jääb tsiviilõigusest välja kaubandusõigus (Mattila 2002: 173).

4 Pandektid (Pandectae) ehk Digestid (Digesta) on keiser Justinianuse korraldusel 530-533 a. koostatud 50 raamatust koosnev väljavõtete kogum klassikalise ajastu juriidilisest kirjandusest, Corpus luris Civilis'e tähtsaim ja mahukaim osa (Adomeit jt 2005: 47).

5 Dig. 1.1.1.2: Privatum ius tripertitum est: collectum etenim est ex naturalibus praeceptis aut gentium aut civilibus. ('Eraõigus koosneb kolmest osast: see on nimelt kokku kogutud loomuõiguse, rahvaste õiguse või tsiviilõiguse normidest.'); Dig. 1.1.9: Nam quod quisque populus ipse sibi ius constituit, id ipsius proprium civitatis est vocaturque ius civile. ('Nimelt see õigus, mille iga rahvas ise on endale määranud, on selle riigi kodanike oma ja seda kutsutakse tsiviilõiguseks.') (Autori tõlge.) 
hakkas välja kujunema keskajal, mil õigusteadus keskendus eelkõige Corpus iuris civilis'e nende osade uurimisele, mis puudutavad õigussuhteid üksikisikute vahel. See mõjutas aja jooksul ka keelekasutust ning nii omandas kõnealune termin Euroopas oma praeguse tähenduse - üksikisikute vahelisi suhteid reguleeriv normide kogum (Mattila 2002: 172-173, Roland, Boyer 1998: 240-241).

\section{Uurimismaterjal}

Tekst on sotsiaalse interaktsiooni keeleline vorm (Halliday 2007: 195) ning tema funktsiooni järgi määratletakse teksti liik. Autor loob teatud tunnustega ja teatud tähendusega teksti. Funktsionaalsest aspektist on teksti koostamine eesmärgipärane keelekasutus, keeleliste valikute tegemisel lähtutakse teksti eesmärgist ja funktsioonist (Kasik 2007: 168). Siin uuritavad opppevahendid liigituvad teadusteksti valdkonda. Teadusteksti eesmärk ei ole ainult edastada teadusala puudutavat infot, vaid uurida, laiendada ja selgitada oma valdkonna sisu (Beaugrande, Dressler 1981: 192, Love 2002: 76).

Olen varem analüüsinud ladina termineid juriidilistes teadusartiklites (Ristikivi 2007, 2008), siin käsitlen õpikuid. Õpiku funktsioon on eelkõige tutvustada teadusala ja selle terminoloogiat, anda (esmaseid) teadmisi. Laiemas mõttes õpikud ja teadusartiklid kattuvad, pidades silmas, et mõlemad sisaldavad käsitletava valdkonna oskussõnavara ja retoorilisi funktsioone. Samas võib neid kitsamalt käsitleda eraldi tekstiliikidena, mis erinevad näiteks diskursuse sisu poolest (õpikud esitavad olemasolevat, teadusartiklid uut teadmist), samuti osalussuhte poolest (õpikute puhul on autori ja lugeja suhe enamasti ebavõrdne, artiklite puhul pigem tasakaalustatud ja võrdne) (Bhatia 2002: 32-33). Eestis on sobiliku õpiku puudumisel sageli õppematerjalina kasutusel eestikeelsed teadusartiklid. Õigusteaduse õppetöös kasutatakse ka ajakirja Juridica. Samas keskenduvad selle ajakirja artiklid enamasti mõnele kitsamale küsimusele, näiteks kommenteeritakse uut õigusakti, analüüsitakse õiguspraktikat jne.

Uurimismaterjaliks on valitud tsiviilõiguse eri harude õpikud, mille hulgas on neli eestikeelset originaalõpikut (Tiivel 2007, Kull 1999, Liin 2005, Orgo jt 2003) ja neli saksa keelest tõlgitud õpikut (Schwab, Prütting 1995, Schlechtriem 2000, Brox 2003, Lüderitz 2005). Perekonnaõigust esindab praeguse seisuga ainult tõlkeõpik (Lüderitz 2005), tööõigust üksnes eestikeelne originaalõpik (Orgo jt 2003). Seega jaguneb oma- ja tôlkematerjal võrdselt tsiviilõiguse tähtsamate ja tänapäeva õigust rohkem mõjutanud valdkondade vahel. Samuti on võrdses olukorras perekonnaõigus ja tööõigus, mõlemad valdkonnad on kujunenud ajalooliselt Rooma õigusega mitte otseses seoses. Valdkondi esindavad järgmised õpikud:

1) asjaõigus: Tiivel 2007, Schwab, Prütting 1995;

2) võlaõigus: Kull 1999, Schlechtriem 2000;

3) pärimisõigus: Liin 2005, Brox 2003;

4) perekonnaõigus: Lüderitz 2005;

5) tööõigus: Orgo jt 2003.

Mahuliselt sisaldab uuritav materjal kokku 2723 lehekülge, sellest Eesti autorite õppekirjandus moodustab 1151 lehekülge ning Saksa tõlkeõpikud 1572 lehekülge. 


\section{Ladina terminite hulk}

Ladina õigustermineid oli kokku 158, neid esines igas õpikus. ${ }^{6}$ Esinemissageduse järgi reastusid õpikud järgmiselt.

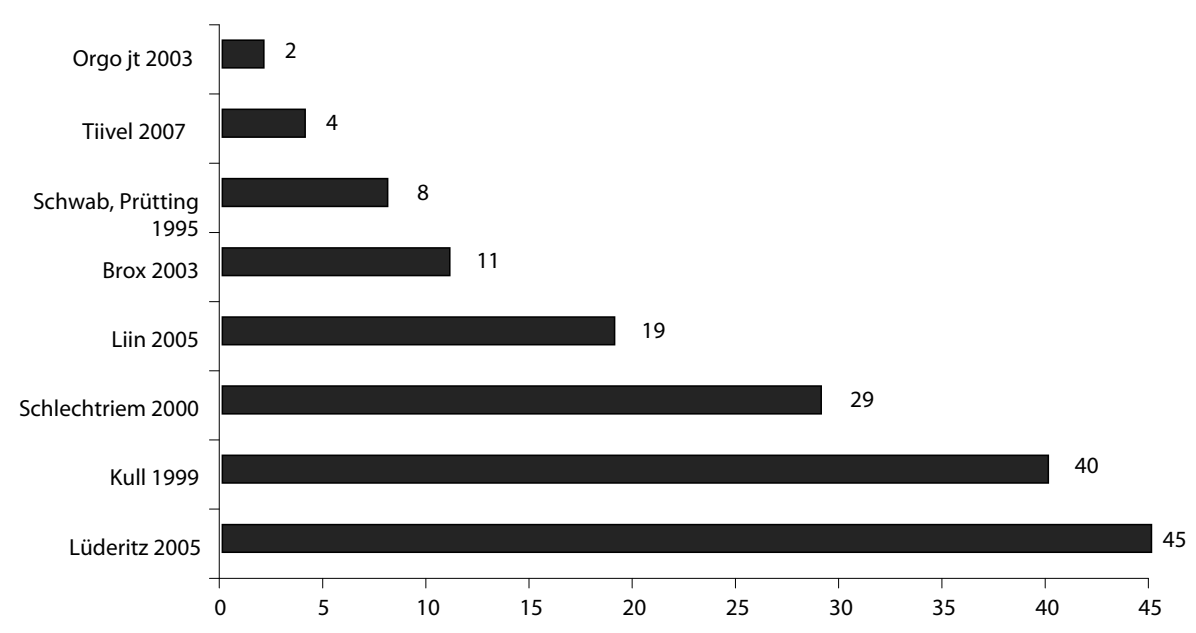

Joonis 1. Ladina terminite absoluutne hulk tsiviilõiguse õpikutes

Terminikasutuse erinevus tsiviilõiguse eri valdkondades tuleb väga selgelt välja (vt joonis 1). Väga vähe võib leida ladina termineid tööõiguse ja asjaõiguse õpikutest (Orgo jt - kõigest 2, Tiivel 2007 - 4 terminit, Schwab, Prütting 1995 - 8 terminit). Pärimisõiguse õpikutes on ladina termineid mõnevõrra rohkem: 11 (Brox 2003) ja 19 (Liin 2005). Märgatavalt rohkem esineb ladina keelt võlaõiguse materjalides: 29 (Schlechtriem 2000) ja 40 (Kull 1999). Perekonnaõiguse õpikus esineb ladina väljendeid veelgi rohkem: 45 (Lüderitz 2005).

Kuna uurimusse valitud õpikud olid väga erineva leheküljemahuga, ulatudes (Kull 1999) puhul 136 leheküljest kuni (Tiivel 2007) 496 leheküljeni (vt tabel 1), võrdlesin ka terminite esinemist uurimismaterjali mahu kohta. Eesti autorite neljas õpikus (kokku $1151 \mathrm{lk}$ ) esineb ladina termineid kokku 65 - keskmiselt kasutatakse ladinakeelseid väljendeid iga 17 lehekülje järel. Neljas tõlkeõpikus (kokku 1572 lk) leidus 93 ladina terminit, mis annab sageduseks ühe termini iga 16 lehekülje järel. Kui võtta ladina terminite esinemissageduse määramisel aluseks terminite ja õpiku lehekülgede arvu suhe (vt tabel 1), siis on esikohal (Kull 1999) - 0,29 väljendit lehekülje kohta. Järgneb (Lüderitz 2005) - 0,1. Peaaegu võrdselt on termineid lehekülje kohta (Schlechtriem 2000) ja (Liin 2005) õpikutes - vastavalt 0,09 ja 0,08. Maha jäävad (Brox 2003) ja (Schwab, Prütting 1995) - vastavalt 0,03 ja 0,02 ladina väljendit lehekülje kohta. Kõige vähem on ladina keelt kasutanud (Tiivel 2007) ning (Orgo jt 2003) - ainult o,01 terminit.

6 Tänan Kersti Jõgit abi eest terminite väljakirjutamisel. 
Tabel 1. Ladina terminite esinemine õpikutes

\begin{tabular}{|l|c|c|c|}
\hline & Terminite arv & Lehekülgi & Termineid Ik kohta \\
\hline Lüderitz 2005 & 45 & 441 & 0,10 \\
\hline Kull 1999 & 40 & 136 & 0,29 \\
\hline Schlechtriem 2000 & 29 & 340 & 0,09 \\
\hline Liin 2005 & 19 & 227 & 0,08 \\
\hline Brox 2003 & 11 & 426 & 0,03 \\
\hline Schwab, Prütting 1995 & 8 & 365 & 0,02 \\
\hline Tiivel 2007 & 4 & 496 & 0,01 \\
\hline Orgo jt 2003 & 2 & 292 & 0,01 \\
\hline
\end{tabular}

Võib tähele panna, et ehkki Saksa õiguskultuuris on ladina terminite kasutamisel pikk traditsioon ning neid leidub sealse õiguskeele kõigis valdkondades, ei ole siin vaadeldud tõlkeõpikutes terminite esinemine märkimisväärselt suurem kui eesti õpikutes. Samas on ladina keelest pärit ainese kasutus Eesti ja Saksa autorite töödes sarnane, kui käsitletakse sama valdkonda. Näiteks palju termineid võib leida (nii terminite üldarvu kui suhet õpiku mahuga arvestades) Eesti ja Saksa autorite puhul võlaõiguse juures (vrd Kull 1999 ja Schlechtriem 2000), millele järgneb pärimisõiguse valdkond (vrd Liin 2005 ja Brox 2003). Oluliselt vähem on termineid asjaõiguse õpikutes (vrd Tiivel 2007ja Schwab, Prütting 1995). Perekonnaõiguses on aga termineid kasutatud väga rohkelt (Lüderitz 2005). Kahjuks ei ole selles valdkonnas kõrvale võtta eesti õpikut. Tööõiguse valdkonnas (Orgo jt 2003) esineb vaid paar ladina terminit, ent puudub võrdlusmaterjal saksa õppekirjandusest.

Hüpotees terminikasutuse seosest ajaloolise arenguga leiab nende andmete põhjal osalist kinnitust: ladina keel esineb sageli võlaõiguses ja pärimisõiguses, mille sõnavara pärineb Rooma õigusest. Samas oli ladina termineid väga vähe asjaõiguse õpikutes, mis samuti on terminoloogia kujundanud juba antiigis ja mõjutab oluliselt tänapäevast arusaama asjaõigusest. Tööõigus on valdkond, mis ei ole kujunenud Rooma õiguse baasil ning selles õpikus (Orgo jt 2003) esineb ka ladina keelt väga harva. Üllatav on aga perekonnaõiguse õpikus (Lüderitz 2005) väga rohkelt kasutatud ladina terminite hulk, sest sellel tsiviilõiguse harul pole Antiik-Rooma perekonnaõiguse temaatikaga tihedaid seoseid. Kuidas seda seletada? Keelekasutus on subjektiivne ning peegeldab ühtlasi autori keelelisi harjumusi ja terminoloogilisi eelistusi. (Lüderitz 2005) õpiku puhul põhineb ladina terminite kasutamine ilmselt just ajaloolistel traditsioonidel, olles õiguskeele loomulik osa.

\section{Õpikutes esinenud ladina terminid}

Teadusvaldkonna terminoloogilise ühtsuse aluseks on ühtne mõistevõrgustik. Õigusmõistete puhul rõhutatakse eeskätt nende funktsionaalsust ja seotust õigusjärelmitega, s.t nad on defineeritud õiguslike tagajärgede kaudu, mis on nendega seotud (Neumann 2001: 784). Samas ei ole õigusmõiste tähistamine vaba nagu muude terminite puhul (Kerge 2004: 33). Juriidilised terminid peavad täpselt ja täielikult edasi andma sellega tähistatud mõistete sisu. Õigusterminitelt nõutakse täpsust, efektiivsust ja arusaadavust (Cornu 1990, Mattila 2002, Oksaar 1999).

Eelkõige esinevadki ladina terminid tsiviilōiguse õpikutes oma põhifunktsioonis: kui normatiivsed argumendid, mis kannavad spetsiifilist juriidilist informatsiooni (Kramer 1995: 141-142). Kuna õiguse keel on tihedalt seotud õiguslike traditsioo- 
nide, ajaloo ja kultuuriga, võib kitsalt juriidiliste terminite kõrval õpikutest leida ka teksti illustreerivaid ja üldkäibivaid ladina väljendeid. Osaliselt on see nn juriidilise retoorika küsimus: ladina keelt kasutatakse stiilielemendina, esteetilise meediumina või professionaalse kompetentsi väljendusena (Mattila 2006a: 136). Kõigist siin analüüsitud terminitest moodustavad sellised väljendid samas väga väikese osa ehk 5,7 \% sõnavarast.7 Siia rühma paigutub 9 väljendit: ad hoc 'selleks; kindlaks juhtumiks', eo ipso 'iseenesest; just seeläbi', expressis verbis 'sõnaselgelt, rõhutatult', iunctim 'ühendatult, seoses', lege artis 'oskusnõuete kohaselt', mutatis mutandis 'vajalike muudatustega', prima facie 'esmapilgul', status quo 'praegune oluvõrd või seisund' ja ultima ratio 'viimne vahend; äärmine vajadus'. Samas on piiri juriidilise argumentatsiooni ja retoorika vahele küllaltki raske tõmmata selliste väljendite puhul, mis võivad juriidilises kontekstis omandada spetsiifilise tähenduse. Ehkki juriidiliseks loetakse kitsamas tähenduses eelkõige sellised terminid, mida ei ole võimalik kasutada õigussuhte väliselt või mille vältimatuks eelduseks on õigussuhe, võivad laiemas tähenduses olla juriidilised ka need väljendid, mida võib küll kasutada ka muus seoses, kuid millel õigusteaduses on spetsiifiline tähendus (Mattila 2002: 170-171). Väljendid nagu ad hoc, ultima ratio, prima facie ongi näiteks sellised, mis kuuluvad küll üldkeelde, kuid mida juristid võivad kasutada ka juriidilises seoses.

Lisaks õigusväljenditele esineb uuritavas materjalis ka kaks meditsiiniterminit: in vitro ja sclerosis multiplex. Termin in vitro esines kaks korda (Lüderitz 2005) perekonnaõiguse ja üks kord (Brox 2003) pärimisõiguse õpikus. Termin sclerosis multiplex esines perekonnaõiguse õpikus ühe korra. Selline terminikasutus juhib tähelepanu asjaolule, et oskuskeelel on võrreldes üldkeelega oma spetsiifika. Õiguskeele vahenditeks on üldkeele neutraalne sõnavara, õigusterminid, samuti reguleeritavate valdkondade terminid ja tänapäevane kirjakeele grammatika (Kerge 1995: 6). See tähendab, et õigustekstidel on küll oma spetsiifika, kuid juriidiliste terminite kõrval puutub õiguskeel kokku lisaks üldkeelele ka õigusteksti esemeks oleva eluvaldkonna oskusterminitega (Narits 1997: 80-82).

Kõige sagedamini esinesid tsiviilõiguse õpikutes järgmised terminid (vt tabel 2). Peamine osa terminitest esines uurimismaterjalis ühe korra. 13 terminit esines vähemalt 2 korda.

Tabel 2. Tsiviilõiguse õpikutes kõige sagedamini esinevad ladinakeelsed terminid

\begin{tabular}{|l|l|c|}
\hline Termin & \multicolumn{1}{|c|}{ Tähendus } & Arv \\
\hline causa & '(lepingu) alus' & 17 \\
\hline aliud & 'muu, teine' & 5 \\
\hline ex nunc & 'alates nüüdsest (hetkest)' & 5 \\
\hline culpa in contrahendo & 'lepingueelne vastutus' & 4 \\
\hline invitatio ad offerendum & 'kutse pakkumuse tegemiseks' & 3 \\
\hline condictio indebiti & 'nõue ekslikult makstud olematu või juba & \\
\hline consensus & tasutud võlasumma tagasisaamiseks' & 3 \\
\hline de lege ferenda & 'üksmeel, nõusolek' & 3 \\
\hline in vitro & 'välja antava seaduse järgi' & 3 \\
\hline ipso iure & 'katseklaasis' & 3 \\
\hline peius & 'õiguse enese põhjal, õiguse enda järgi' & 3 \\
\hline ultima ratio & 'halvem' & 3 \\
\hline
\end{tabular}

7 Võrreldes juriidilise perioodika sõnakasutusega, kus üldtuntud ladina väljendite kasutamine on rohkem levinud, 
Teemade kaupa jagunevad enim kasutatud terminid järgmiselt:

1) asjaõiguse materjalides esines kõige rohkem termin causa (3 korda), kõik teised väljendid esinevad ainult ühe korra;

2) võlaõiguse õpikutes olid kõige sagedamini terminid causa (14 korda), aliud (5), invitatio ad offerendum (4), condictio indebiti (3), culpa in contrahendo (3), peius (3). Vähemalt kaks korda esinesid terminid condictio ob rem, conditio sine causa, consensus, consensus ad idem, ex nunc, ius commune, lex specialis ning mutatis mutandis;

3) pärimisõiguses on sagedamad terminid, mida oli kasutatud vähemalt kaks korda: eo ipso, ex nunc, expressis verbis, hereditas iacens, inter vivos, legis fictio, ipso iure;

4) perekonnaõiguse õpikus esineb kõige rohkem ehk kolm korda termin de lege ferenda. Vähemalt kaks korda on materjalis kasutatud termineid argumentum, ex tunc, in praeteritum non vivitur, in vitro, manus, prima facie;

5) tööõiguse õpikus esineb ainsa ladina väljendina kaks korda termin ultima ratio.

Tähelepanu väärib, et suur osa võlaõiguses nimetatud terminitest pärineb Rooma õigusest. Pärimis-, perekonna- ja tööõiguses on sageli esinevate väljendite hulgas mitmeid selliseid, mis võivad esineda ka teiste õigusvaldkondade juures. Näiteks väljendid de lege ferenda, ex tunc, argumentum, prima facie ja in vitro ei ole tähenduse poolest ainult kitsalt perekonnaõiguse väljendid. Samamoodi võib tööõiguse õpikus kasutatud terminit ultima ratio ja pärimisõiguse materjalides esinenud termineid eo ipso, ex nunc, expressis verbis ja ipso iure ning asjaõiguse õpikutest leitud terminit causa kohata ka õiguskeeles üldiselt. Näitena võib siinjuures välja tuua veel termini bona fides 'heausksus' kasutuse, mis tähenduse poolest on pigem seotud võlaõiguse sõnavaraga. Uuritavates võlaõiguse õpikutes seda väljendit ei kasutatud, küll aga võib selle leida asjaõiguse õppevahendist.

\section{Terminoloogiline variatiivsus}

Kogu uurimismaterjalis sisalduva 158 terminikasutuse juures võib leida 100 erinevat väljendit. Õpikute puhul, mis annavad ülevaate kogu vastavast tsiviilõiguse valdkonnast, on üsna ootuspärane, et sõnavara ei kordu ja tutvustatakse erinevaid termineid.

Joonis 2 näitab, et selgelt eristub teistest perekonnaõiguse õpik (Lüderitz 2005), milles on kasutatud 37 erinevat ladina terminit. Võlaõiguse õpikutes on eesti ja tõlkeõpiku terminite hulk üsna sama - vastavalt 19 (Kull 1999) ja 17 (Schlechtriem 2000). Pärimisõiguses on eesti õpikus (Liin 2005) termineid ligi kolmandiku võrra rohkem kui tõlkeõpikus (Brox 2003), vastavalt 14 ja 10. Asjaõiguses joonistub eesti originaalõpiku (Tiivel 2007) ja tõlkeõpiku (Schwab, Prütting 1995) terminikasutuse vahele suurem vahe: vastavalt 3 ja 8 . Tööõiguse õpikus (Orgo jt 2003) esines ladina termineid kõige vähem, kõigest üks termin kaks korda.

Samas tuleb märkida, et terminite kvantitatiivne ja kvalitatiivne kasutus ei anna uuritava materjali puhul tulemuseks suuri erinevusi. Need autorid, kelle töödest võib leida ladina termineid kõige sagedamini, paistavad enim silma ka kasutatud sõnavara mitmekülgsuse ja vahelduslikkuse osas. 


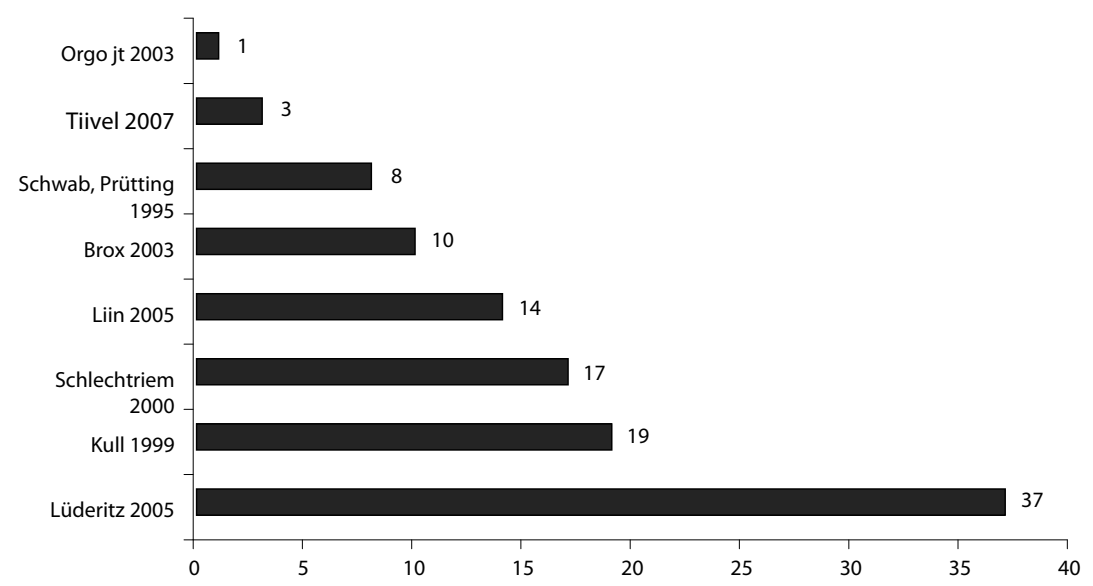

Joonis 2. Terminoloogiline variatiivsus

Eesti ja tõlkeõpikute võrdluses tuleb omakorda tõdeda, et terminoloogiline variatiivsus on eesti õpikutes märkimisväärselt väiksem.

Et võrrelda terminoloogilist variatiivsust tsiviilõiguse valdkondade vahel, on kokku liidetud kõikides sama teemat käsitlenud õpikutes esinenud erinevate ladina terminite arvud (vt joonis 3).

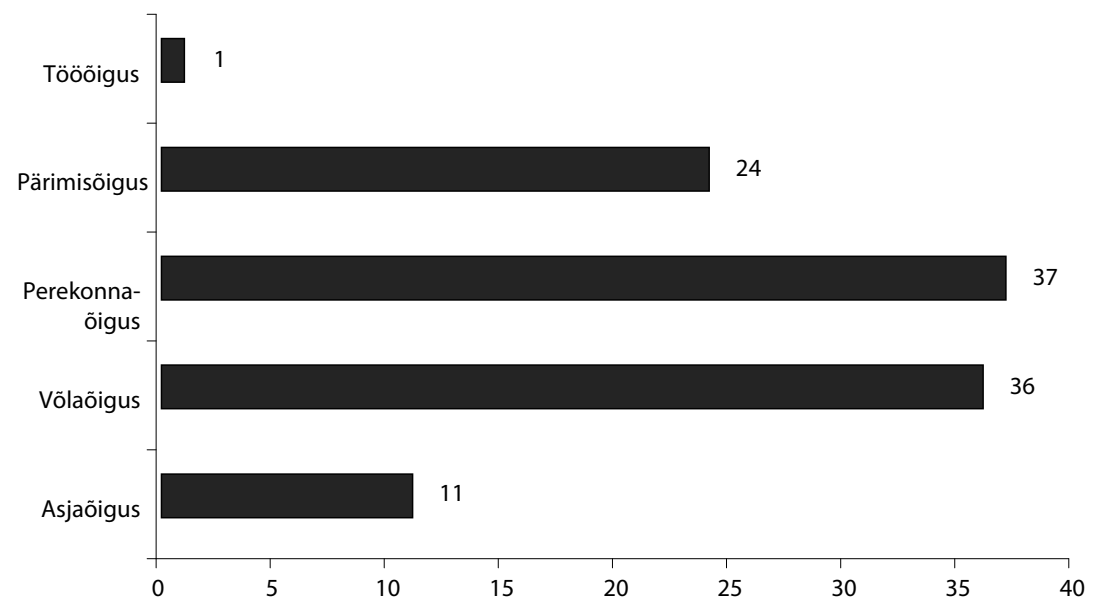

Joonis 3. Variatiivsus tsiviilõiguse valdkondades

Tsiviilõiguse valdkondade võrdlus (joonis 3) näitab, et kõige rohkem võib erinevaid termineid leida võlaõiguse (Kull 1999 ja Schlechtriem 2000) ja perekonnaõiguse (Lüderitz 2005) õpikutest, vastavalt 36 ja 37 eri väljendit. Ligi kolmandiku võrra vähem ehk 24 erinevat terminit esines pärimisõiguse õpikutes (Liin 2005 ja Brox 2003). Asjaõiguse õpikutes (Tiivel 2007 ja Schwab, Prütting 1995) oli erinevaid termineid 11. Tööõiguse puhul (Orgo jt 2003) on kasutatud kaks korda ühte ja sama terminit. 
Ühe õigusvaldkonna terminoloogia uurimisel võib tavaliselt näha, et sõnavara kattub ka selle harude puhul põhimõistete osas: teatud valdkonda iseloomustab kindel ühine tuumiksõnavara. Ehkki käesolevas töös uuritav materjal kuulub kõik tsiviilõiguse alla, ilmneb õpikute sõnavara võrdlemisel, et terminoloogiline ühisosa on üllatavalt väike. Kõige rohkemates teemades esineb väljend ex nunc, mida on kasutatud nii võlaõiguse, pärimisõiguse kui ka perekonnaõiguse õpikus. Väljendeid, mis esinevad vähemalt kahes tsiviilõiguse harus, on kõigest 7: causa, cessio legis, culpa in contrahendo (võlaõiguses ja perekonnaõiguses); in vitro (perekonnaõiguses ja pärimisõiguses); ipso iure, nasciturus (võlaõiguses ja pärimisõiguses); ultima ratio (perekonnaõiguses ja töõõiguses).

Peamiselt esinevad leitud terminid ainult ühe kindla haru materjalides.

Sama teema käsitlemisel ei lange kokku ka eesti ja tõlkeõpikutes esinenud väljendid. Näiteks asjaõiguses on ainult üks selline termin - causa -, mida autorid ühiselt kasutavad. Kõik teised väljendid esinevad asjaõiguses autoritel ainukordselt. Ülejäänud teemade puhul on terminite kokkulangevus sama valdkonna käsitlemisel sama harv või veelgi väiksem. Pärimisõiguses on näiteks samuti ainult üks termin (ipso iure), mis esineb mõlema autori töös. Võlaõiguse õpikutes ei langenud terminikasutus mitte ühegi termini puhul kokku, ehkki üldkasutuse poolest on selle haru autorid kasutanud termineid suhteliselt palju.

Eesti autorite puhul on ühine ainult termin causa, mis esineb võlaõiguse ja asjaõiguse õpikus. Tõlkeõpikutes on eri valdkondade ühised terminid ex nunc, cessio legis, in vitro, ipso iure, nasciturus. Samas ei esinenud ükski nendest terminitest eesti originaalõpikutes. Väljend ultima ratio on ainus, mis esines eesti originaalõpikutest tööõiguse materjalis ning tõlkeõpikutest perekonnaõiguses. Termin causa esineb kahel eesti autoril (asjaõigus ja võlaõigus) ning asjaõiguse tõlkeõpikus.

Tulemus, et eesti ja tõlkeõpikutes ei lange terminid sama teemakäsitluse puhul kokku, on üsna üllatav. Õiguskeele uurijad muidugi viitavad, et õiguskeel erineb teistest erialakeeltest eelkõige selle poolest, et see on seotud ühe kindla ühiskonna ja selle õigussüsteemiga (Lauzière 1974: 111). Ent kas see väide võiks kehtida käesoleval juhul, kui mõlema riigi autorid on kasutanud küll erinevaid, kuid siiski ühtviisi peamiselt Rooma õigusest pärinevaid termineid? Kui võrrelda nii tõlkeõpikutes kui ka eesti õpikutes esinenud termineid ajakirjas Juridica leiduvaga, siis seal on neid kõiki vähemalt ühe korra kasutatud ning seega ei ole need terminid õiguskeeles tundmatud ja võõrad. Kahtlemata on selle artikli uurimismaterjal liiga vähene ning kaugeleulatuvaid järeldusi ladina terminite üldise efektiivsuse kohta rahvusvahelises suhtlemises ei ole mõtet teha. Just asjaolu, et ladina termineid seob ühtne ajalooline taust, kindlustab neile juriidilise identiteedi kandjana kindla koha eri riikide juristide kommunikatsioonis.

\section{Kokkuvõte}

Artikkel käsitles ladina termineid tsiviilõiguse õpikutes. Rooma õigusest pärit ladina õigusterminid kannavad ja vormistavad tsiviilõiguse eriala mõistestikku, nad on aine objekti ja sisu põhilised väljenduselemendid.

Uuritav materjal sisaldas nii eestikeelseid originaalõpikuid kui saksa keelest tõlgitud õppevahendeid. Nende terminikasutuse võrdlemisel ilmneb, et tõlkeõpikutes esineb termineid rohkem nii üldmahult kui ka erinevate terminite kasutuselt. Samas 
erineb tõlkeõpikute terminivara eesti õpikute omast niivõrd palju, et otsest mõju, mis muidu Saksal õigusel on Eesti õigusele, terminoloogilisel tasandil ei saa välja tuua. Tõlkeõpikute terminirohkus võib olla seletatav ajaloolise järjepidevusega. Kui sirvida enne Teist maailmasõda ilmunud eestikeelseid tsiviilõiguse originaalõpikuid, torkab silma, et ladina terminid olid ka Eestis sel perioodil õigushariduse keeles väga laialdaselt kasutusel. Mõtlemapanev on siinjuures veel asjaolu, et Euroopas on sageli ladina keele elementaarkursus ülikooli tulles juba läbitud. Eesti üliõpilastel aga on tihti alles ülikoolis esimene kontakt ladina sõnavaraga ning seetõttu tuleks autoritel rohkem tähelepanu pühendada erialase sõnavara tutvustamisele.

Terminikasutuse võrdlemine tsiviilõiguse valdkondade vahel näitas, et ilmnevad selged vahed nii terminite kvantitatiivsel kui kvalitatiivsel tasandil. Tulemused kinnitasid põhiosas hüpoteesi, et termineid esineb rohkem neis tsiviilõiguse harudes, mille sõnavara on välja kujunenud peamiselt Rooma õiguse baasil, s.t võlaõiguses ja pärimisõiguses. Samas oli ladina termineid väga vähe kasutatud asjaõiguse õpikutes, mis ometi on üks nendest tsiviilõiguse valdkondadest, mis on otseselt Rooma õigusest kujunenud ja mõjutab olulisel määral tänapäevast arusaama asjaõigusest. Tööõiguses, millel on Rooma õigusega ainult kaudsed seosed, kasutati ladina termineid väga vähe. Samas ei leidnud kinnitust oletus, et ladina termineid võiks esineda vähem perekonnaõiguses. Ka selle valdkonna tänapäevane õiguslik käsitlus erineb oluliselt Rooma perekonnaõiguse temaatikast. Uurimuses kasutatud perekonnaõiguse õpikus esines ladina termineid arvuliselt palju, samuti saab seda õppevahendit esile tõsta ka terminoloogilise variatiivsuse poolest.

\section{Viidatud kirjandus}

Adomeit, Klaus; Ristikivi, Merike; Siimets-Gross, Hesi 2005. Ladina-eesti õigussõnastik. Peeter Kask (toim.). Tallinn: Eesti Keele Sihtasutus.

Annus, Amar; Kolk, Kaspar; Puhvel, Jaan; Päll, Janika 2001. Muinasaja seadusekogumike antoloogia. Tallinn: Varrak.

Beaugrande, Robert A. de; Dressler, Wolfgang U. 1981. Introduction to Text Linguistics. London, New York: Longman.

Bhatia, Vijay K. 2002. A generic view of academic discourse. - John Flowerdew (Ed.). Academic Discourse. London: Longman, 21-39.

Birks, Peter; McLeod, G. 1987. Justinian's Institutes. London: Gerald Duckworth \& Co.

Cornu, Gerard 1990. Linguistique juridique. Paris: Montchrestien.

Dig. = Iustiniani Digesta (Corpus Iuris Civilis) 1922. Recognovit Theodorus Mommsen. Berolini: Apud Weidmannos.

Görgen, Andreas 2002. Rechtssprache in der Frühen Neuzeit. Frankfurt am Main: Peter Lang.

Halliday, Michael A. K. 2004. The Language of Science. London, New York: Continuum.

Halliday, Michael A. K. 2007. Language and Society. London, New York: Continuum.

Hattenhauer, Hans 2007. Euroopa õigusajalugu. Tallinn: Juura.

Kasik, Reet 2007. Võimu keel: asutus suhtleb kodanikuga. - Eesti Rakenduslingvistika Ühingu aastaraamat, $3,161-176$.

Kerge, Krista 1995. Õiguskeel, tema vahendid ja väljavaated. - Õiguskeel, 4, 6-8.

Kerge, Krista 2004. Terminid leksikaalse ja grammatilise keelendina. - Sirje Mäearu (toim.). Rahvusvaheline terminoloogiakonverents "Eesti oskuskeel 2003" 10. ja 11. oktoobril 2003. Ettekanded. Tallinn: Eesti Keele Sihtasutus, 19-46.

Koschaker, Paul 1966. Europa und das römische Recht. 4. Aufl. München, Berlin: Beck. 
Kramer, Ernst A. 1995. Lateinische Parömien zur Methode der Rechtsanwendung. - Steuerrecht. Ausgewählte Probleme am Ende des 20. Jahrhunderts. Festschrift zum 65 . Geburtstag von Ernst Höhn. Bern: Verlag Paul Haupt.

Lauzière, Lucie 1974. Un vocabulaire bilingue canadien. - Meta, 24, 109-114.

Love, Alison 2002. Introductory concepts and 'cutting edge' theories: Can the genre of the textbook accommodate both? - John Flowerdew (Ed.). Academic Discourse. London: Longman, 76-92.

Mattila, Heikki E. S. 2002. Vertaileva oikeuslingvistiikka. Helsinki: Kauppakaari Lakimiesliiton Kustannus.

Mattila, Heikki E. S. 2006a. Comparative Legal Linguistics. Aldershot: Ashgate.

Mattila, Heikki E. S. 2006b. De Latinitate recentiorum doctrinarum ad iura hereditaria pertinentium. - Syntymästä kuolemaan, oikeudesta informaatioon. Ahti Saarenpää 60 vuotta. Suomalaisen Lakimiesyhtistyksen julkaisuja E-sarja, 17, 113-136.

Narits, Raul 1997. Õigusteaduse metodoloogia I. Tallinn: Juura.

Neumann, Ulfrid 2001. Juristide keel. - Akadeemia, 4, 782-794.

Oksaar, Els 1999. Kõnekeel, erialakeel, õiguskeel. - Juridica, 4, 199-207.

Ristikivi, Merike 2007. Lexica iuridica in Juridica: Latin terms as a reflection of Europanisation of Estonian legal culture. - Juridica International, 12, 173-179.

Ristikivi, Merike 2008. Ladina õigusterminite vormilisest ja sisulisest korrektsusest. - Eesti Rakenduslingvistika Ühingu aastaraamat, 4, 157-170.

Roland, Henri; Boyer, Laurent 1998. Locutions latines du droit français. Paris: Litec.

Senn, Marcel 2007. Rechtsgeschichte - ein kulturhistorischer Grundriss. 4. Aufl. Zürich: Schulthess.

Tamm, Ditlev 1997. Roman law and European legal history. Copenhagen: DJØF Publishing.

Wieacker, Franz 1967. Privatrechtsgeschichte der Neuzeit. 2. Aufl. Göttingen: Vandenhoeck \& Ruprecht.

\section{Õpikud}

Brox, Hans 2003. Pärimisõigus. Tallinn: Juura.

Kull, Irene 1999. Lepinguõigus. Tallinn: Juura.

Liin, Urve 2005. Pärimisõigus. Tallinn: Ilo.

Lüderitz, Alexander 2005. Perekonnaõigus. Tallinn: Juura.

Orgo, Inge-Maret; Muda, Merle; Tavits, Gaabriel; Treier, Thea 2003. Tööõigus. Tallinn: Juura.

Schlechtriem, Peter 200o. Võlaõigus. Eriosa. Tallinn: Juura.

Schwab, Karl Heinz; Prütting, Hanns 1995. Asjaõigus. Tallinn: Juura.

Tiivel, Rein 2007. Asjaõigus. Tallinn: Juura.

Merike Ristikivi (Tartu Ülikool) on erialalt klassikaline filoloog, uurimisteemaks on ladina keele mõjutused eesti õiguskeeles.

merike.ristikivi@ut.ee 


\title{
LATIN TERMS IN CIVIL LAW: ORIGINAL TEXTBOOKS IN ESTONIAN VERSUS TRANSLATED TEXTBOOKS
}

\author{
Merike Ristikivi \\ University of Tartu
}

The article discusses the occurrence of Latin terms in Estonian textbooks on civil law. As the object of study there have been selected eight textbooks that focus on different areas of civil law (property law, right of obligation, right of succession, family law and labour law). The genre type of a text is identified according to the function that the text acquires in communicative interaction. The materials analysed in the current article are classified as scientific texts. The purpose of a scientific text is to impart knowledge and to examine, elaborate and explicate the factual information concerning a particular discipline. The target group of the study aid which qualifies as a scientific text comprises university students, and its function is the introduction to the historical trends and the current principles of the various areas of civil law, as well as familiarisation with specialist lexis (Beaugrande, Dressler 1981: 192, Love 2002: 76).

The terminological unity within the discipline is achieved by the common network of concepts. The legal terminology in Continental Europe has been modelled on the reception of Roman Law which in the Middle Ages mainly consisted of investigating and teaching Roman civil law. Thus, the continental law developed for several centuries on the basis of the Latin language and it relies heavily on the system of concepts stemming from Roman civil law. Therefore the role of Latin terms in civil law is more significant than in other areas of law.

Since the influence of German law on the Estonian legal culture has been considerable and German law has also been taken as the basis of current legislation in Estonia, the textbooks chosen for this study include besides original Estonian textbooks also study aids translated into Estonian from German. to the study compares the usage of Latin terms in Estonian books and translated books. The results of the research indicate that German influences on Estonian legislation can also be observed on the terminological level. In translated study aids, Latin terms are more abundant, and the authors use a greater variety of terms.

In addition, the article analyses the differences among the uses of Latin expressions in the various areas of civil law as viewed from the historical perspective, presuming that the usage of terminology is closely connected to the development of the subfields. The results largely confirm the hypothesis that Latin terms are more commonly used in those areas of civil law whose vocabulary has largely developed from Roman law, i.e. right of obligation and right of succession. Labour law, which is connected with Roman law only remotely, has adopted relatively few Latin phrases. Property law textbooks also contain few Latin terms despite the fact that this is one of the areas of civil law that have developed directly from Roman Law. Similarly, the hypothesis that Latin terms may be less numerous in family law could not be confirmed. In this area, the modern legal treatment differs significantly from the 
family law matters in Roman Law. As for the family law study aid under scrutiny in the current research, it appeared that a great number of various Latin terms can be detected in this textbook.

Keywords: legal language, terminology, language area studies, language contact, Latin, Estonian 